\title{
MARÓTI ANDOR
}

\section{Merre tovább andragógia? - A fogalomváltások tanulságairól}

\section{A kezdetek}

1956 őszén a debreceni egyetemen Durkó Mátyás speciálkollégiumot hirdetett a népművelés történelmi, elméleti és módszertani ismereteiről. Tény, hogy akkor a népmüvelésnek még nem volt kidolgozott elmélete és módszertana, amit erről mégis el lehetett mondani, azt Durkó jórészt a pedagógiából kölcsönözte, és ezt vetítette rá a gyakorlati tapasztalatokra. Mégsem volt ez teljesen megalapozatlan. A debreceni egyetemnek volt ugyanis egy legendás hírü, akkor már nem élö tanára, Karácsony Sándor, akit évekkel korábban Durkó is hallgatott, és akitől jó néhány gondolatot át tudott venni, még ha azok nem is illettek az ötvenes évek müvelődéspolitikájába. Karácsony ugyan pedagógiát tanított az egyetemen, de a második világháborút követő években az Országos Szabadmüvelődési Tanács elnöke volt, és ennek megfelelően többször írt a felnőttek neveléséröl. Különösen egy megállapítása volt elgondolkoztató, ami azonban épp a népmüvelési felfogás ellen szólt: „A népmüvelésben más műveli a népet, a szabadmüvelődésben maga müvelődik a nép - ahogy igénye és kedve tartja”. S figyelmeztetésként hozzátette: „Bele ne essünk tehát a régi hibába...passzív valaminek ne vegyük a kultúrálandó felet... A kultúrálandó fél csak abban részesíthető, amit igényel. Hiába tömök, eröltetek bele egyebet, visszautasítja. A kultúrálandó fél igazán termőföld, azt termi, amihez kedve van, az gyökerezik meg benne, ami bele való".(1)

1948-ban volt Révfülöpön egy országos szabadmüvelödési konferencia, amire Karácsony Sándort már meg se hívták, $\mathrm{s}$ ahol a Kulturális Minisztérium képviselője részletes bírálatot mondott a szabadmüvelődésről. Támadta romantikus felfogását, mely idealizálja a parasztság közt élő népi kultúrát, így a múltat fölébe helyezi a jelennek. Ezt a következtetést Karácsonynak az a megállapítása váltotta ki, mely szerint a nálunk uralkodó kultúra idegen, ezért vissza kell nyúlnunk a XVII. századig, amikor a protestáns prédikátorok szövegei még közvetlenül kapcsolódtak a magyar kultúrához. Szerinte ezzel a fordulattal alapozható meg az új magyar kultúra. S minthogy ez már csak a parasztság körében él, a müvelödésnek is a folklorisztikus gyökereire kell építeni, ,alulról fölfelé ható erővé” kell válnia, mert az minden olyan társadalomban él, amely „nem mechanikus, hanem organikus jellegü”.(2) Karácsony a müvelődés demokratikus modelljét fogalmazta meg, ami azonban szemben állt az államilag felülről irányított kultúrával. A révfülöpi konferencián a szabadmüvelődésről mondott bírálat szerint ,a társadalmi öntevékenység” mindaddig nem időszerü, amíg a reakciós erők elleni osztályharc be nem fejeződik. Addig a művelődésügy nem lehet semleges, szolgálnia kell az ideológiai-politikai meggyőzést.(3) E bírálat jele volt annak, hogy a politikai hatalom fel akarja számolni a szabadmüvelődés szervezeteit, és helyébe a központilag irányított népmüvelést állítja. És ez rövidesen be is következett.

Amikor évekkel később Durkó Mátyás kialakította népmüvelési szemináriumát, már csak ehhez a fogalomhoz kötődve indíthatta el kezdeményezését, megkísérelve, hogy ezen belül fejlessze ki a dogmatikus szólamoktól mentes, hatékony gyakorlat elméleti alapjait. Voltak társai, akik vállalták az egyes tantárgyak tanítását. Nekik köszönhető, hogy az évtized végére a népmüvelést a debreceni egyetemen „harmadik szakként” fogadta el az illetékes minisztérium, kiterjesztve az egyetemi képzés egész idejére.

Ezekben az években Budapesten, a Népmüvelési Intézet Oktatási osztálya kezdeményezte, hogy a népmüvelés helyet kapjon az Eötvös Loránd Tudományegyetemen is. A képzés 
tantervének kidolgozásában jelentős szerepe volt Novák Józsefnek. Ő korábban a szekszárdi múzeum igazgatója, majd a dombóvári tanítóképző tanára volt, és országosan a honismereti mozgalom szervezőjeként lett ismert. Az Intézet tervét támogatta a Müvelődésügyi Minisztérium Közművelődési Főosztálya, sőt megnyerte ennek a minisztérium akkori vezetőjét, Benke Valériát is. Amikor azonban a minisztérium tárgyalni kezdett az új szak bevezetéséről az egyetem vezetőivel, kiderült, hogy erős az ellenállás a professzorok többségénél. Ök azzal érveltek, hogy a népmüvelés nem tudomány. Az ott dolgozóknak nincs szükségük egyetemi végzettségre, amit tudniuk kell, azt tanfolyamokon is megszerezhetik. A gyakorlati tapasztalatok persze igazolták ezt az érvelést, a fóállásban népmüvelési munkakört betöltők zömének ekkor valóban csekély volt az iskolai végzettsége. Ez már az ötvenes évek elejétől így alakult, mert a kinevezésük feltétele a politikai megbízhatóság volt, a feladat, amit végezniük kellett, olyan kultúra terjesztése, amelynek ideológiai-politikai hatása van. Jellemző volt, hogy a népmüvelést ekkor kulturális agitációnak tekintették. A helyzet az 1956-os forradalom után változott meg. 1958-ban megjelentek a müvelődéspolitika új irányelvei, amelyek megfogalmazták, a társadalmi átalakulás feltétele az emberek ,szocialista tudata", s mert ez még hiányzik, ezért a tudatformálás a jövőben kiemelt fontosságú feladat. Nem elég tehát a kultúrát terjeszteni, annak hatásával is foglalkozni kell. Erre hivatkozva be lehetett bizonyítani, korszerü müveltség nélkül ez lehetetlen, ahhoz viszont, hogy e követelmény széles körben érvényesüljön, magas szinten képzett szakemberek kellenek. Elengedhetetlen tehát az egyetemi-föiskolai képzésük és alapjaként a tudományosan kiérlelt elmélet folyamatos kidolgozása, fejlesztése.

\section{Az első lépések}

Feltételezhető, elsősorban ez járult hozzá ahhoz, hogy a népmüvelés 1961-től fő szak lett a budapesti egyetemen, egy évvel később Debrecenben is. Az ELTE Bölcsészkarán támogatta bevezetését a Kar dékánja, Tálasi István, a tárgyi néprajzi tanszék vezetője, emellett László Gyula a régészeti tanszék tanára és Kovács Máté, a könyvtári tanszék vezetője, aki azt is vállalta, hogy a tanszékéhez csatolva elfogadja a Népmüvelési Szakcsoportot és a hozzájuk tartozó szakot. Ennek hatására a Kar és az Egyetem Tanácsa is megszavazta az új képzés indítását. A művelődéspolitika országos vezetői persze úgy fogták fel a népmüvelést, hogy az kádereket képez majd a politikai meggyőzés számára, és csak később döbbentek rá arra, hogy nem ez valósult meg. Röviddel a népmüvelési képzés kezdete után Aczél György látogatta meg az egyetemet, és előadást tartott a népmüvelés-szak hallgatóinak. Amikor az előadása után lekísértem őt az egyetem kapujához, azzal búcsúzott, „hívjanak meg ide tanársegédnek”. Erre persze nem került sor, de később, 1964-ben egy országos népmüvelési ankéton a pártközpont kulturális osztályának vezetője és a müvelődési minisztérium egyik miniszterhelyettese már keményen bírálta meg a két egyetem népmüvelés-szakán tanító tanárokat, akik „elméletieskednek”, ahelyett, hogy a gyakorlatra képeznék hallgatóikat. Furcsa volt tölük hallani, hogy az egyetemen nem elméletre van szükség. Ez a vád persze nem is ezt tagadta, valójában arra irányult, hogy a szak tanárai elkezdték feldolgozni más országok szakirodalmát, és azok ismeretében tették szóvá a hazai gyakorlat korszerütlenségét, rossz hatékonyságát. Egyúttal javasolták a központilag kijelölt nevelési feladatok helyett a gyakorlatnak a helyi szükségletekre építését és a programokon résztvevők aktív közremüködését.

Az így felhasznált szakirodalmat a szak oktatói részben lengyel és jugoszláv szerzők munkáiból, részben az elérhető nyugatnémet, francia, angol és amerikai szerzők munkáiból vették át. Közöttük jelentősebb hatást a varsói egyetem tanárának, Bogdan Suchodolski-nak a könyve jelentette, ami „A jövőnek nevelőnk” címmel jelent meg magyarul, s amelyben egy 
hosszabb fejezet szólt a felnőttoktatásról. Döntő módon járult hozzá az elmélet kialakításához az UNESCO 1960-ban tartott világkonferenciája a kanadai Montrealban. Ez a konferencia először mondta ki a „permanens képzés és tanulás” szükségességét, felismerve, hogy a gyorsan változó világ miatt mellőzhetetlen a gyermekkori oktatás felnőttkori folytatása, a felnőttek sajátos helyzetének és gondolkodásának megfelelően. Ettől kezdve egyetemeinken szakunk oktatói népművelésen már felnőttoktatást, felnőttképzést értettek, sőt Durkó Mátyás ragaszkodott a „felnőttnevelés” fogalmához, amit ô a személyiség fejlesztésével azonosított.

Az 1968-ban megjelent könyvének címe: „Felnőttnevelés és népmüvelés” lett, amivel azt érzékeltette, hogy e két fogalom közül az első a hangsúlyos, míg a népművelést annak inkább elözményekén lehet tekinteni. Abban a kultúra átadása még pótló jellegü volt, a csekély iskolázottságú emberek felemelési szándékával, míg a felnőttnevelés már a társadalom egészére kiterjedő sajátos feladatrendszert jelent, a fiatalkori képzettség kiegészítésével.

1967-ben alakult meg a Magyar Pedagógia Társaság Felnőttoktatási Szakosztálya. Elnöke Durkó Mátyás lett, szervező titkára pedig Novák József. Nekik köszönhető, hogy ez a szakosztály már kezdetben is eleven viták színhelye lett, és hozzájárult a felnőttoktatás korszerüsítéséhez. Jelentős szerepe volt ebben az Országos Pedagógiai Intézet felnőttoktatási osztályának, amelynek vezetője Csoma Gyula sikeresen kapcsolta össze az iskolai és az iskolán kívüli felnőttoktatás és képzés tapasztalatait és elméleti alapjait. Lényegében e szakosztály megalapítói kezdeményezték még 1966-ban a „Munka és müvelödés” c. nemzetközi konferenciát, amit a Tudományos Akadémián a Tudományos Ismeretterjesztő Társulat és a Szakszervezetek Országos Tanácsának Kulturális Osztálya hívott össze a szomszédos országok képviselöinek részvételével. A rendezvény bevezető referátumát én tartottam. Előadásomnak egyetlen részletét idézem fel, mert az bizonyította, hogy miként lehetett megfelelni az ilyen alkalmak iránt mutatkozó ideológiai-politikai elvárásoknak úgy, hogy az közben mégis lehetőséget adjon a dogmatikus gondolkodással párosuló szokványos gyakorlat bírálatára. Antonio Gramscit, az olasz kommunista filozófust idéztem a következő megállapításával: „Le kell szoknunk arról, és fel kell hagynunk azzal, hogy a kultúrát enciklopédikus tudásnak tekintsük; ebben a szemléletben az ember csak mint befogadó van jelen, akit meg kell tölteni és tele kell tömni empirikus adatokkal, nyers és összefüggéstelen tényekkel, amelyeket szótár módjára raktároz el agyában, hogy aztán a külső világból jövő ösztönzés hatására minden alkalommal megadhassa a választ... A kultúra egészen más dolog. Saját belső énünk megszervezése és fegyelme, saját személyiségünk birtokba vétele, olyan magasabb fokú öntudat megszerzése, amelynek révén képessé válunk történelmi jelentőségünk, az életben betöltött funkciónk, jogaink és kötelességeink megértésére”.(4) Ha valaki figyelmesen követte ezt az érvelést, felismerhette, hogy Gramsci szavai ellentétben állnak azzal, amit nálunk a müvelődéspolitika hirdetett. Aszerint ugyanis a kulturális forradalom nem más, mint a kulturális javak széleskörü terjesztése, és a haladónak mondott értékeik elfogadtatása. Ebben a felfogásban azonban az egyéni autonóm gondolkodás szóba sem került, a müvelődéspolitika a személyes fejlődést az össztársadalmi folyamatokhoz való igazodásban látta.

Ezt az eseményt azért is idéztem fel, mert érzékelteti, hogy a népmüvelés elméleti megalapozásában érlelődött már a személyiség-központú felfogás, amely a gyakorlatban a hangsúly áthelyezését célozta a kultúra átadásáról annak átvételére, személyes feldolgozására. Ez mutatkozott meg abban is, hogy az egyoldalú nevelési szemlélet szociológiai és pszichológiai megközelítéssel egészült ki egyetemi oktatásunkban, s amikor ennek módszertani vonatkozásait kerestük, el kellett jutnunk a kiscsoportos foglalkozások és az aktivizáló módszerek ajánlásához. A kiscsoportos képzés jelentőségét az észak-európai országokban elterjedt tanulókörökkel lehetett bizonyítani, amelyek a népföiskolákkal együtt a 
felnőtt lakosság egyharmadát képesek megnyerni a közösségi keretekben folyó rendszeres önképzésre. Az aktivizáló módszerek ismertetésére egy érdekes élményt idézhetek fel 1973ból. Az előző évben a Tudományos Ismeretterjesztő Társulat Csongrád-megyei szervezetének titkára keresett fel azzal a kéréssel, hogy segítsek kialakítani Szegeden a pedagógiai nyári egyetem mellett egy müvelődéselméletit. Vállalkoztam arra, hogy megtervezzem a tematikáját, és javasoljak hozzá előadókat. A cél az volt, hogy elméleti megalapozottsággal szóljunk a mủvelődés gyakorlati problémáiról. Ennek az előadássorozatnak olyan sikere volt, hogy a következő évben már csaknem kétszer annyian jelentkeztek a folytatására. Ez azonban már andragógiai volt. Nemcsak azt fejtettük ki külföldi példák felhasználásával, hogy mit jelent a felnőttoktatás korszerüsége, de módszertanilag is újszerü volt, amit alkalmaztunk. Néhány előadáshoz ugyanis kis csoportos vitát kapcsoltunk, lehetőséget adva arra, hogy a résztvevők szabadon fejtsék ki véleményüket a hallottakról. A program leginkább sikeres része azonban az volt, amikor Várnagy Mariannal együtt a gyakorlatban mutattuk be a különböző aktivizáló módszereket. Az úgynevezett 66-os módszer ismertetése úgy történt, hogy fölvetettünk egy problémát, és azt kértük, hogy az egymás mellett és egymás mögött ülők alkossanak 6 fös csoportokat, és hat perc alatt beszéljék meg a probléma megoldási lehetőségét. A teremben kb. 200 ember ült, akik csodálkozva fogadták felszólításunkat, mert ilyet még sohasem tapasztaltak. Ök úgy gondolták, ilyen létszámú hallgatóság csak előadást hallgathat. S amikor bíztattuk őket, hogy mégis csak próbálják meg, amire kértük őket, csakhamar zsongás töltötte be a termet, majd a megadott idő lejárta után a csoportok képviselői egymás után mondták el, mire jutottak a megbeszéléseiken. Kiderült, hogy a szóban forgó probléma sokoldalú megközelítése tárulhatott fel így, sokkal gazdagabban, mintha arról egy előadó beszélt volna. A szerepjátékhoz egy tipikus helyzetet vázoltunk fel: egy településen megüresedik egy müvelödési ház igazgatói munkaköre, és egy bizottságnak el kell döntenie, kit válasszanak a számításba vehetők közül. Önként jelentkezőket kértünk a bizottság tagjainak megszemélyesítésére, akik az adott hely különböző funkcióban levő vezetői. Nagy sikere volt annak, ahogy az egyes személyeket a közremüködők sajátos szóhasználatukban, érvelésükben jelenítették meg, de az is tanulságos volt, hogy mit jelenthet egy probléma megoldása, ha azt különböző nézőpontokból megközelítve próbáljuk felfogni, és megkíséreljük ezeket összhangba hozni. E módszerek bemutatásával persze nem szórakoztatni akartuk a résztvevőket, hanem azt szerettük volna elérni, hogy az aktivizáló módszereket gyakorlatukban alkalmazzák is, és ne elégedjenek meg az előadások szervezésével.

A következő évben kultúraelméleti tematikája volt ennek a nyári egyetemnek, az előadásokhoz kapcsolódó kiscsoportos vitákat a résztvevők már ismerősként alkalmazták. Megváltozott a szokványos kapcsolat az előadók és hallgatóik között: a hallgatóság egyenlő jogú partnerré vált, s nem egy előadásnál azt megelőzve tárta fel, mely kérdésekre várnak választ az előadás hallgatói. Ezek után nem volt meglepő, hogy a további évekre már nem kértek fel a müvelődéselméleti nyári egyetem programjának tervezésére és gyakorlati levezetésére. Túlságosan nagy szerepet kaptak a résztvevők, ez szokatlan volt még akkor abban a társadalmi-politikai légkörben.

\section{A fogalom változása}

A 70-es években országosan változás történt a népmüvelés fogalmának használatában. Az 1970-es országos népművelési konferenciát befejezése után már közművelődésinek nevezték, ami jelezte, hogy ezt a területet a korábbinál szélesebb értelemben, össztársadalmi jelenségként kell felfogni, úgy hogy az a kulturális élet egészét érintse. Ugyanez a szemlélet határozta meg az 1976-os közmüvelödési törvényt is, amely elvileg már nemcsak az 
illetékesség körét bővítette, de azzal, hogy „művelés” helyett „művelődést” mondott, a hangsúlyt a kultúra közvetítéséröl annak elsajátítására tette át.(5) Meglepett, hogy a fogalomváltás indoklását adó miniszteri beszéd olyan érvelést használt, ami emlékeztetett a szabadművelődés elméleti alapjait kidolgozó Karácsony Sándoréra. Később tudtam meg, hogy ezt a beszédet a miniszter csak felolvasta, de nem ő írta. Azt a minisztérium egyik dolgozója fogalmazta meg, aki korábban az egyetemen nálunk tanult, és ismerte Karácsony Sándor érvelését.

A közmüvelődési törvény elfogadása után remélni lehetett, hogy a népművelés korszerübb lesz. A gyakorlat azonban mégsem igazodott ehhez. A müvelődési házakra korlátozódó népmüvelés továbbra is fenntartotta a régi fogalmat, és abban egyedül önmagát tekintette a közmüvelődésben illetékesnek, nem is kereste az együttmüködést más intézményekkel. (Pl. az iskolákkal, a könyvtárakkal). Egy jellemző esetet tudok erről felidézni. Ekkor született meg az a javaslat, hogy az eleinte „nevelési központnak”, később ,általános müvelődési központnak” nevezett újtipusú intézményben több intézmény kerüljön közös vezetés alá, és ez lehetővé tegye az együttmüködésüket. Alkalmam volt megismerni a csepeli ÁMK helyzetét, ahol a pedagógusok panaszolták, iskolájukban a tanulók tanulmányi átlaga: 2.6. Ennek oka szerintük az, hogy a többségük hátrányos helyzetü családokból érkezik, a szülők iskolai végzettsége csekély, egyesek börtönviseltek, és ezt a hátrányt a tanárok nem tudják kiegyenlíteni. Megkérdeztem az intézmény müvelődési házi részlegét, ők mit tesznek ennek a problémának a megoldására. Azt felelték, ez nem az ő feladatuk, Ök a gyerekeknek bábelőadásokat, a nagyobbaknak pedig discót adnak. Együttmüködésről tehát szó sem volt, az egyes részlegek egymástól elkülönülten dolgoztak. Mindegyik a kultúra közvetítésében gondolkodott, és nem azokban az emberekben, akiknek a müvelődéséért valamit tenni akarnak.

Hasonló tapasztalatom volt az egyetemen, ahol a rokonnak tekinthető szakok együttmüködéséről volt szó ekkor egy komplex elmélet alapján. A Művelődéskutató Intézet igazgatója, Vitányi Iván javasolta, a Bölcsészkaron a muzeológiai szakok, a könyvtár szak és a népmúvelés közös mủvelődéstörténeti, müvelődéselméleti alapról induljanak, és erre építve specializálódjanak. Javaslatát valamennyien elutasították. A múzeumi szakok vezetői azt mondták, a múzeumok tudományos intézmények, nem népmüvelésiek. A könyvtár-szak akkori vezetője ugyanígy érvelt. És itt nem egyszerüen a tudományos és a gyakorlati profil szembeállítása jelent meg, hanem az a meggyőződés is, mely szerint a kultúra közvetítésében a tárgyak feldolgozása jelentősebb, mint az emberekre tett hatás.

Ezekben az években már széles körben terjedt el az „élethosszig tartó tanulás” szükségessége. Hozzájárult a felnőttoktatás elismeréséhez, anélkül azonban, hogy a fiatalkori és felnőttkori tanulást-tanítást a szakmai közvélemény egységes rendszerként fogta volna fel. Ha ez az összefüggés világossá vált volna, észre kellett volna venni, hogy a fiatalok iskolai oktatásában a tananyag megtanításával egyenértékü feladat az iskolán túli önképzés igényének és képességének a kifejlesztése. Úgy, hogy szerves kapcsolat épüljön ki a felnőttoktatás és közmüvelődés intézményeivel. Ilyen kapcsolódás igénye azonban hiányzott az érdekeltek gondolkodásából. Jellemző problémaként említhetem meg, hogy még a Pedagógiai Társaság Felnőttoktatási Szakosztályán belül sem sikerült igazán elérni ekkor, hogy a szakosztály tagjai között közös legyen az érdeklődés a felnőttoktatás problematikája iránt. A szakosztály tagjai ugyanis különböző ágazatokban dolgoztak, a többségüket kizárólag csak annak a szükebb területnek a problémái érdekelték. Elkülönült egymástól az iskolák esti és levelező tagozatán tanítók érdeklődése, a munkaerő-piaci esélyeket javító szaktanfolyamok szervezőié, a vezetőképzésben, a távoktatásban dolgozó szakembereké, a tudományos ismeretterjesztés szervezőié, az egészségügyi felvilágosításban érdekelteké, a rádió és a televízió müsorait 
készítőké, a büntetés-végrehajtás intézményeiben dolgozó nevelőtiszteké. Az ágazati szemlélet ellent mondott annak is, hogy a részterületeket átfogó elméleti háttér nagyobb érdeklődést váltson ki; a gyakorlatban dolgozók többsége nem érezte, hogy ez jelentős mértékben hozzájárulna a munkájuk hatékonyságának javításához. Amit a Pedagógiai Társaság Felnőttoktatási Szakosztálya mégis sikerrel valósított meg: az a nemzetközi látókör szélesítése volt. A külföldi konferenciákról szóló beszámolók és a külföldi szakemberek előadásai mindig nagy érdeklődést váltottak ki.

Véleményem szerint a közmüvelődési szemlélet sem tudott érvényesülni a kultúraközvetítő gyakorlatban. A különböző kulturális intézmények közmüvelödési illetékességüket - ha egyáltalában gondolkoztak erről - a látogatók számának növelésében látták, gyakorlatilag tehát a hatást mennyiségi vonatkozásában fogták fel, s nem minőségileg. Amikor a rádió és a televízió elindította a Mindenki iskoláját, hogy segítse az iskolai végzettség javulását, reméltük, hogy ez a kezdeményezés szélesebbé válhat a tömegkommunikációban. Felajánlottuk, hogy az egyetemen felnőttoktatási-közmüvelődési profillal speciális irányt alakítunk ki a tömegkommunikációnál dolgozók számára. Akkor a Felnőttoktatási Szakosztályunk titkára, Csiby Sándor volt a rádió és a televízió oktatási osztályának vezetője, és ő nagymértékben segítette ennek az elgondolásnak a kidolgozását. Az együttmüködésből mégsem lett semmi sem, a rádió és a televízió szakemberei ugyanis kijelentették, az ő feladatuk nem a népmüvelés, nem is az oktatás, hanem a hírközlés és a szórakoztatás. A kulturális intézmények többsége hasonlóképp a szórakoztatást tekintette feladatának. És ez a vélemény ma különösen erősödik, amikor a kultúra átadásában fö szerepe a pénzben kifejezhetö bevételnek van. Ebböl következik az is, hogy nem számít, mennyire alacsonyak a kielégítendő igények, és ennek megfelelően a közvetítendő kultúra színvonala sem. Az ilyen felfogás mellett magától értetődő, hogy ezek az intézmények arra sem tartanak igényt, hogy a közönségkapcsolatukhoz közmüvelődési szakértőt alkalmazzanak.

Az egyetemek népmüvelés-szakán az andragógia mégis mind nagyobb helyet kapott. Noha a népművelés-szakot ekkor már müvelődésszervezőnek nevezték, tantervében két nagyobb egység volt: az egyik a kultúrával kapcsolódott össze, és tartalmazta a müvelödéstörténetet, a kultúra filozófiáját és szociológiáját, a másik pedig az andragógia neveléselméletét, pszichológiáját és módszertanát. És amikor a 21. század első évtizedében a hazai felsőoktatás áttért a bolognai rendszerre, ez utóbbi határozta meg képzésünk elnevezését, tekintettel arra, hogy ez a fogalom volt az, amit különböző külföldi egyetemeken - az Egyesült Államoktól kezdve az európai egyetemek jó részében - meg lehetett találni, igaz, többségükben felnőttoktatás, felnőttképzés néven. Nálunk meglepően sok felsőoktatási intézmény vállalkozott ekkor az andragógia bevezetésére. Még a tanítóképzők is felsorakoztak az egyetemek és tanárképző föiskolák mellé, talán azért, mert remélték, ezzel növelni tudják hallgatóik számát, és az anyagi helyzetük is erősödhet. Az első években valóban sokan jelentkeztek erre a szakra, az andragógia egy ideig a legdivatosabb tanulási lehetőségnek számított. Mindaddig, amíg nagymértékben lecsökkent az államilag támogatott, ösztöndíjas hallgatói létszám. Ennek következtében az andragógia szakot meghirdető felsőoktatási intézmények száma is kevesebb lett.

Az ELTE-n e probléma nem volt érezhető, a szakra jelentkezők száma lényegében nem csökkent. És nem került válságba a képzés tartalma sem, mert oktatói közt ott voltak azok, akik a felnőttoktatás elméletével, módszertanával már egyetemi tanulmányaik közben megismerkedtek, és a felkészültségüket azóta rendszeresen tovább fejlesztették. Szabóné Molnár Anna, Kraiciné Szokoly Mária és Striker Sándor még a népmüvelés-szakon szereztek egyetemi végzettséget, s lettek később ennek az alapnak tovább fejlesztői, amikor e szak 
andragógia-szakká alakult át. Az andragógia átfogó jellegét mutatta, hogy több speciális irányt bontott ki, így a személyügyi, az oktatásszervezői, a munkavállalás tanácsadói és a humán erőforrás menedzseri szakirányban. Itt kapott helyet a müvelődésszervezői szakirány is, a régi népmüvelési szak maradványaként. Bár a látszat az, hogy ez a szakirány idegen elem az andragógiában, egy rokon vonás kétségtelenül mégis felfedezhető közöttük. Ahogy a népmüvelést a közművelődés váltotta fel, a felnőttoktatás kultúraközvetítő jellegét váltja fel napjainkban a tanulásközpontú felfogás. Igaz, e váltásokat mindkét területen erösen akadályozza a szokványos gyakorlati felfogás, amelyre jellemző, hogy elméleti alapok nélkül próbál eredményeket elérni. Eredményei azonban a résztvevők számának növelésében mutatkoznak meg, és semmit sem árulnak el az információk elsajátításának, a készségek és képességek fejlődésének színvonaláról. Ehhez persze nélkülözhetetlen a tanulási folyamatok empirikus elemzése, ami szerves kapcsolatot teremthet elmélet és gyakorlat között, mert feltárja, mi is történik a tanulás folyamatában, és megmutatja, mit kell a gyakorlatban tenni e folyamat kedvezőbb alakulása érdekében.

Észak-Európa országaiban a felnőttek egyharmada már rendszeresen képzi magát. Ez az arány nálunk alig néhány százalék. Remélhető, hogy előbb-utóbb felzárkózunk, ha a gazdaságunkat korszerübbé, a közvéleményt pedig demokratikusabbá akarjuk tenni. Az, hogy egy ilyen irányváltás a jövőben bekövetkezik-e, az nagymértékben függ a közvélemény alakulásától. Ezért szükséges lenne, hogy az andragógiáról szóló véleménycsere ne maradjon szük szakmai körben, állásfoglalásai terjedjenek a társadalom egészében.

\section{Hivatkozások}

(1) Karácsony S.: Új Szántás. 1947. 1. 3-4. o.

(2) Karácsony S.: Ugyanott

(3) E. Kovács Kálmán: A szabadművelődés kérdéseiről. Új Szántás. 1948. 8-9.

(4) A. Gramsci: Marxizmus, kultúra, müvészet. Kossuth Kiadó, 1965. 188-189. o.

(5) Törvény a közmüvelödésröl. Kossuth Kiadó, 1976. 